\title{
Evaluation of Seismic Performance of Buildings Constructed on Hillside Slope of Doronka Village-Egypt
}

\author{
Ahmed Abdelraheem Farghaly \\ Civil and Architectural Buildings, Faculty of Industrial Education, Sohag University, Sohag 82524, Egypt \\ Correspondence should be addressed to Ahmed Abdelraheem Farghaly; khodary20002000@yahoo.com
}

Received 30 January 2014; Accepted 4 March 2014; Published 10 April 2014

Academic Editors: E. J. Sapountzakis and I. Smith

Copyright (C) 2014 Ahmed Abdelraheem Farghaly. This is an open access article distributed under the Creative Commons Attribution License, which permits unrestricted use, distribution, and reproduction in any medium, provided the original work is properly cited.

\begin{abstract}
Construction on the hillside slope is more challenging to the structural engineer, especially under seismic load due to the presence of a powerful earthquake in addition to the forces of sliding slope itself. Regarding the population growth and narrowness of available lands, people take hillside slopes to build their houses. One of the main sources of seismic vulnerability in Egypt is represented by the instability of slopes; therefore, this is a subject of great significance, particularly in view of the growing attention that has been recently dedicated to the reduction of seismic hazard. This paper evaluates the seismic performance of Doronka city buildings constructed on rocky hillside slope and its foundations system by studying base shear, acceleration, and displacements. The stability of the slope was first evaluated under seismic loads and then the stability of constructed buildings was checked on the hillside slope. The results of study show that these buildings will collapse if subjected to earthquake even if its peak ground acceleration (PGA) magnitude is less than $0.25 \mathrm{~g}$, but the hillside slope remains stable within a high earthquake magnitude.
\end{abstract}

\section{Introduction}

Doronka village is in the south of Cairo (about $375 \mathrm{~km}$ ) and was subjected to flood in 1996, and most of its houses were destroyed, therefore, its people tended to construct their houses on the hillside of the town away from the danger of future flood. The nature of the soil of the hillside is a rocky soil, which is a very hard soil used to find traditional buildings on it, so most of the buildings constructed on hillside in Doronka town were founded as stepped (the foundation found to be on more than one level in most cases) and raft foundations.

The response of a slope under seismic loading is determined by the temporal and spatial distribution of the seismic forces in the soil mass, which in turn depend on the characteristics of the seismic input and on the mechanical properties of the soil. In general, any foundation design should meet four essential requirements: (1) adequate Geotechnical capacity of soil/rock surrounding the foundation with a specified safety against ultimate failure, (2) acceptable total or differential settlements under static and dynamic loads, (3) adequate overall stability of slopes in the vicinity of a footing/mat, and (4) constructability with solutions for anticipated problems.

The ground response analyses can be performed under 1D or $2 \mathrm{D}$ conditions, and the nonlinear soil behavior is usually described through the equivalent linear method that provides a reasonable estimate of soil response for moderate levels of shearing intensity provided that no significant excess pore water pressure develop during seismic shaking.

\section{Analysis of Slope Stability: Overview}

Numerous methods have been developed for assessing the stability of soil slopes, most of which are based on the concept of ideally plastic response when failure is imminent. Among them, the limit equilibrium methods enjoy wide acceptance due to their reasonable agreement with reality and their simplicity [1]. Complex soil profiles, seepage, and a variety of loading conditions can be easily dealt with [2]. Limit equilibrium solutions, however, are not rigorous. To be called rigorous, a solution must satisfy the equilibrium equations, 


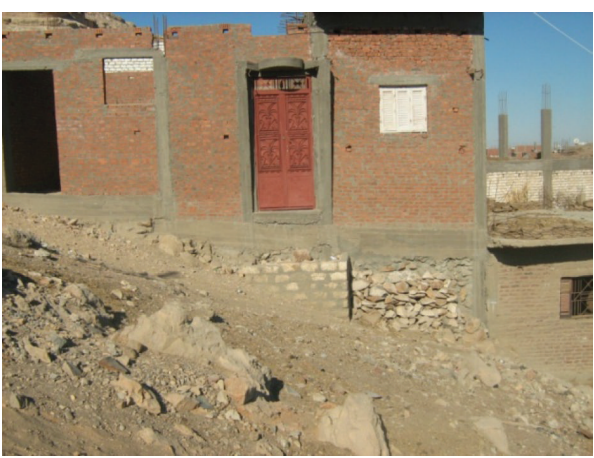

(a) High slope angle with stepped foundation

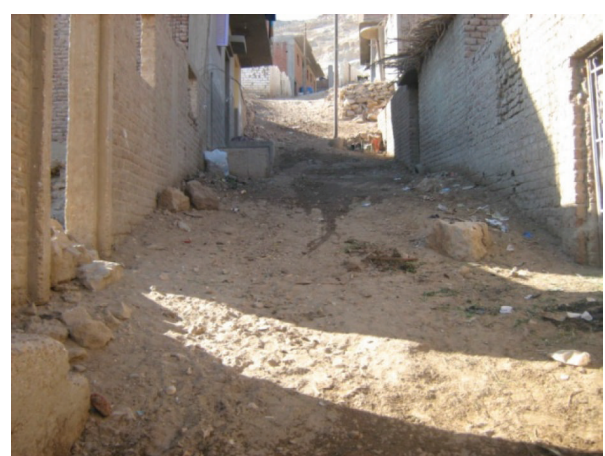

(b) Small slope angle with stepped foundation

FIGURE 1: The techniques of constructing building on hillside slope in Doronka village.

the compatibility conditions, the constitutive relations of all materials, and the boundary conditions.

Limit equilibrium methods often violate the stress boundary conditions; they do not enforce an appropriate plastic flow rule for the soil, while the developing stresses may not everywhere obey the requirement for nonincidence of soil strength. Moreover, the introduction of assumptions necessary to remove static indeterminacy leads to kinematically inadmissible collapse mechanisms.

The finite element (FE) method is an alternative approach employed with two different methodologies: (a) those that search for the critical slip surface using stress fields obtained from the stress and deformation FE analysis and (b) those that compute the factor of safety through an iterative finite element analysis, by the "strength reduction technique" [3]. In the latter category of methods, finite elements are utilized to model the development of shear zones and the progressive failure of soil. The advantages of the FE approach over the conventional slope stability methods can be summarized as follows.

(i) No assumption needs to be made a priori about the shape and location of the slip surface. Failure occurs naturally within the soil when the applied shear stresses exceed the shear strength of the soil mass.

(ii) The solution is kinematically admissible, and there are no arbitrary assumptions about the slice side forces.

(iii) It can capture progressive failure phenomena and provide information about the displacement field until the ultimate state.

(iv) It can readily (if not easily) handle irregular slope geometries in 2 and 3 dimensions, complex soil stratigraphy, and calculation of low quantities (due to steady seepage or to transient flow).

Pitilakis [4] and Anastasopoulos et al. [5] discussed the $2 \mathrm{D}$ wave propagation effects, and it is perhaps leading to "topographic" amplification, are taken into account in their analysis. The authors have been shown that such effects may lead to increased amplitude of ground shaking near the crest of the slope.
Figure 1 shows the techniques of building constructed in Doronka city (area of study), which clears that they are constructed on stepped isolated footings or raft foundation.

Latha and Garaga [6] proved that the factor of safety for the slope was reduced by $46 \%$ with the application of earthquake loads in pseudostatic analysis than static conditions and it is recommended to flatten the slope from $50^{\circ}$ to $43^{\circ}$ to avoid wedging failures at all pier locations.

Pandey et al. [7] studied the behavior of buildings on hill slope through a 3D analysis of the building, in which the static pushover analysis and response spectrum analysis have been conducted on five buildings with varying support conditions. These buildings have been analyzed for different soil conditions (hard, medium, and soft soils) idealized by equivalent springs. In general, it is found that response, reduction factor decreases with increasing time period but is expected to be constant beyond a certain value of the time period.

Kourkoulis et al. [8] studied parametrically the effects of foundation type (isolated footings versus a rigid raft) on the position of the sliding surface, on the foundation total and differential displacements and on the distress of the foundation slab and superstructure columns. The authors showed that a frame structure founded on a properly designed raft could survive the combined effects of slope failure and ground shaking, even if the latter is the result of a strong base excitation amplified by the soil layer and slope topography.

Failure mechanisms caused by shear strength reduction assume different characteristics depending on soil behavior, ductile or brittle, and soil type, granular or cohesive, as discussed by Rampello et al. [9]. These mechanisms can be analyzed in the static condition following the seismic event, using conventional limit equilibrium methods, eventually accounting for the increase of pore water pressure and the degradation of strength parameters induced by earthquake loading.

On the contrary, when slope instability is produced by earthquake-induced inertial forces, a progressive development of slope displacements occurs for the duration of ground motion only. Accordingly, evaluation of slope response to earthquake loading should be carried out, in 
principle, using analytical procedures which account for time-dependent seismic action and that allow an evaluation of the induced displacement to be obtained. If a pseudostatic approach is adopted in this case, the equivalent seismic coefficients used in limit equilibrium calculations must be calibrated against specifying levels of slope performance and in turn defined by specifying threshold values of earthquakeinduced displacements. In fact, in the pseudostatic approach the safety factor provides an indirect estimate of the seismic performance of the slope to earthquake loading, while under static conditions it represents a measure of the distance from a potential failure mechanism.

In situ soil slopes and embankments are often reinforced with nails to improve their static and seismic performance. Michalowski and You [10] developed an approximate method based on the kinematic approach of limit analysis to estimate the permanent displacement of geosynthetic-reinforced soil slopes subjected to earthquake loading. Chavan et al. [11] verified this approximate method through finite element (FE) analysis of nails and soil slopes considering the soil and the nails as nonlinear and linear elastic materials, respectively. Radiation damping has been considered by using LysmerKuhlemeyer (L-K) dampers at the soil boundaries of the FE model. Soil is assumed to be dry and cohesionless and analyzed under plane strain conditions. The permanent displacements from approximate method and FE analysis have been compared. It is found that the displacements from FE analysis are considerable (more than 10\%) less than those from approximate method.

Krishnamoorthy [12] obtained a procedure to evaluate the factor of safety of the slope $(1: 1)$ subjected to seismic load using Monte Carlo technique. The proposed method can be used to obtain simply the factor of safety of the slope and deformation of the slope.

Mavrouli et al. [13] presented an analytical methodology to evaluate rock slope stability under seismic conditions by considering the geomechanical and topographic properties of a slope. The objective is to locate potential rock fall source areas and evaluate their susceptibility in terms of probability of failure. For this purpose, the slope face of a study area is discretized into cells having homogenous aspect, slope angle, rock properties, and joint set orientations. A pseudostatic limit equilibrium analysis is performed for each cell, whereby the destabilizing effect of an earthquake is represented by a horizontal force. The value of this force is calculated by linear interpolation between the peak horizontal ground acceleration PGA at the base and the top of the slope. The ground acceleration at the top of the slope is increased by $50 \%$ to account for topographic amplification. The uncertainty associated with the joint dip is taken into account using the Monte Carlo method. The proposed methodology was applied to a study site with moderate seismicity in Sol'a de Santa Coloma, located in the Principality of Andorra. The results of the analysis are consistent with the spatial distribution of historical rock falls that have occurred since 1997. Moreover, the results indicate that, for the studied area, (1) the most important factor controlling the rock fall susceptibility of the slope is the water pressure in joints and (2) earthquake shaking with PGA of $0.16 \mathrm{~g}$ will cause a significant increase in rock fall activity only if water levels in the joints are greater than $50 \%$ of the joint height.

Figure 2 illustrates the models used for the analysis of different cases for constructing both isolated and raft foundation cases. The angles of slopes $\phi$ are $60^{\circ}, 45^{\circ}$, and $25^{\circ}$ depending on the slope location in the nature (dimensions of the models were in $\mathrm{m}$ ). The finite-element (FE) analyses can be successfully utilized to model the generation of sliding failure surfaces in the slope, reproducing similar failure surfaces with those derived from limit-equilibrium and limit-analysis methods and leading to similar yield accelerations. But the capability to treat realistically the dynamic response to ground shaking is an exclusive attribute of the numerical (FE) methodology, not of the pseudostatic limit equilibrium/analysis methods. An additional capability of the numerical (FE) methodology is that any structurefoundation system can be placed on the slope. For the purpose of the present study, a discretization of $0.5 \mathrm{~m} \times 0.5 \mathrm{~m}$ has been adopted as in Kourkoulis et al. [8].

The finite element (FE) method is one of many stressesdeformation methods. It is widely accepted for its accuracy in modeling different geological geotechnical phenomena as it implements physical laws. During the last decade, major improvements in efficiency and configuration have made it easier and cheaper to use and therefore it has become a more common tool in science and engineering.

\section{Selection of Adequate Accelerographs}

The recorded accelerographs of Northridge (1989) and El Centro (1940) earthquakes are shown in Figure 3. Since there are no accelerographs available (neither recorded nor predicted based on the seismic risk analyses) in the area, the above accelerographs are selected for seismic analyses of the model. According to the Egyptian code of practice for seismic resistant design of buildings [14], the city of Doronka is classified as the area by relatively low seismic risk, and the design acceleration of the area is recommended to $0.25 \mathrm{~g}$. Thus, the above mentioned accelerographs have been scaled and corrected for this amount. Egypt in the last years was classified as high seismic regions so the research will analyse the buildings constructed on hillside slope subjected to earthquake acceleration $0.25,0.5$, and $1 \mathrm{~g}$ to cover all possibilities of how earthquake force can affect the area. Time history analysis is carried out using SAP200 [15] program considering the factor of acceleration $0.25,0.5$, and $1 \mathrm{~g}$ and nonlinear analysis with 4000 step at $40 \mathrm{sec}$ for both time history used earthquakes (El Centro and Northridge earthquakes). The time history corresponding to 5\% damping is considered which is reasonable for concrete structure.

\section{Model Description}

The $2 \mathrm{D}$ building model consists of frame elements as beam and column. The column dimension is $50 \times 50 \mathrm{~cm}$ and the beam section is $25 \times 50 \mathrm{~cm}$ all over the height of the building. The foundation is chosen to be either raft or isolated foundation in the analyses. A 4-story building was modeled 


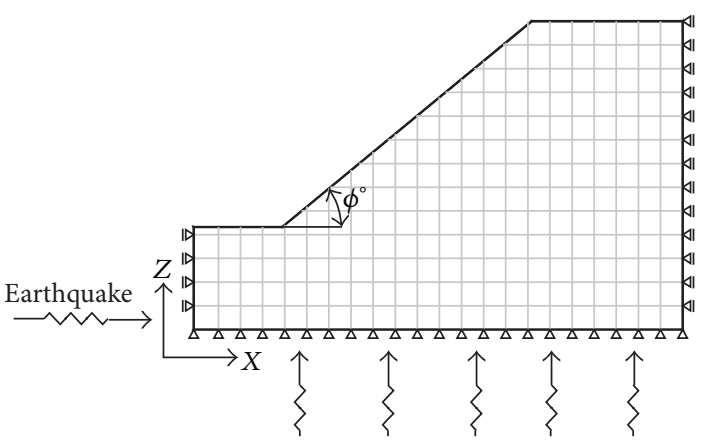

(a) Slope with angle $\phi$ with directions of earthquakes

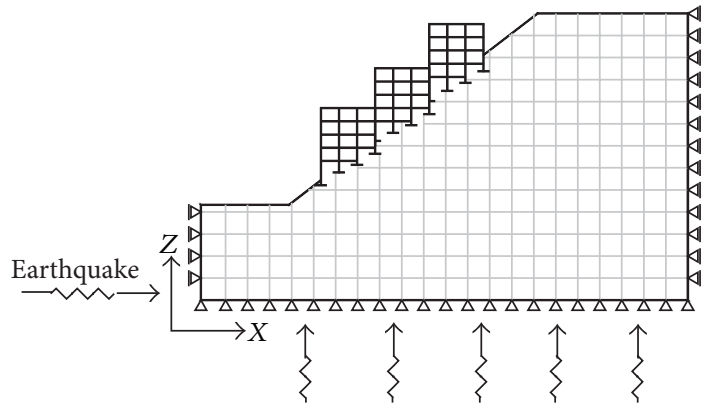

(c) Stepped buildings on slope constructed on isolated footing

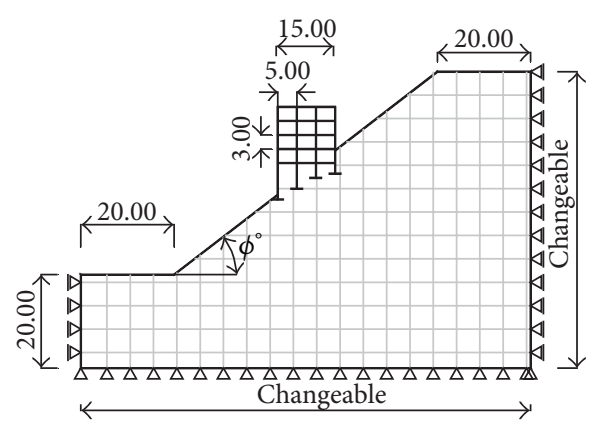

(b) Building on slope constructed on isolated footing

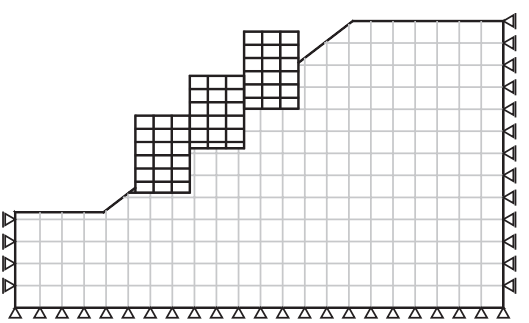

(d) Stepped buildings on slopes constructed on raft foundation

FIGURE 2: Finite element mesh: in the area of the slope the discretization is denser $(0.5 \mathrm{~m} \times 0.5 \mathrm{~m}$ quadrilateral elements).

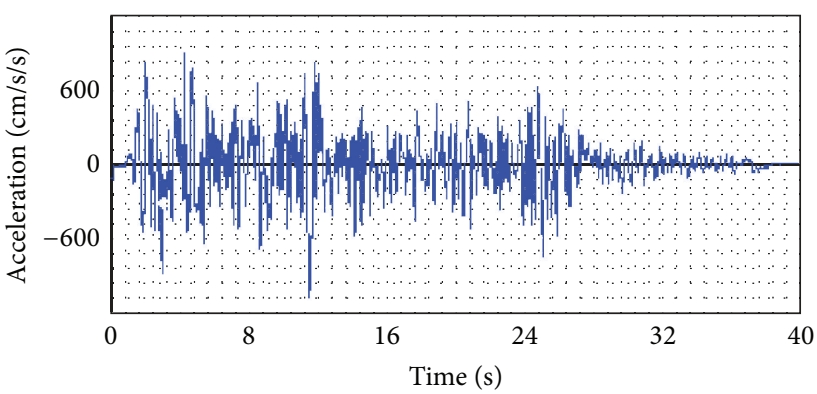

(a) El Centro

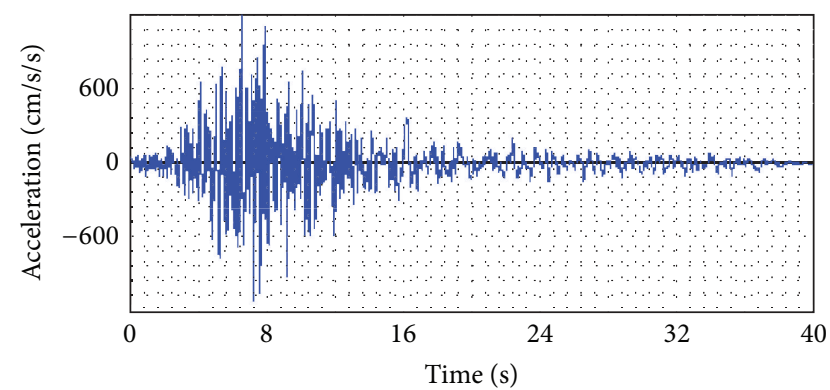

(b) Northridge

FIGURE 3: Acceleration time histories of the earthquakes in N-S direction.

with a $3 \mathrm{~m}$ height (each story) and a $15 \mathrm{~m}$ length, as shown in Figure 2 .

No matter what type and size of RC structure is under investigation the finite element method (FEM) is the most accurate and reliable numerical technique for assessing the demands on structure components in both $2 \mathrm{D}$ and $3 \mathrm{D}$ domains.

The inelastic analysis is performed, and the failure criterion used for both the soil and the structure members has to be stated as well.

Frame members primarily not only serve to carry the majority of gravity loads in a building but also serve as part of lateral resisting systems. Bernoulli-Euler beam theory and Timoshenko beam theory Hjelmstad [16] if considering shear effects of deep beam are widely used and have been implemented in most computer-based frame analysis packages.
A Beam element was loaded with constant distributed loads equal to $2.50 \mathrm{ton} / \mathrm{m}^{\prime}$ at all floor levels, in addition to own weight of elements.

\section{Results and Analysis}

To evaluate the performance of buildings constructed on hillside slopes at Doronka city two main parts were studied: the first part is the performance of the building with a different foundation system to seismic loads on the hillside slope and presenting the straining actions of them resulting from two earthquakes (El Centro and Northridge earthquakes) analyses in steps, that is, first $0.25 \mathrm{~g}, 0.5 \mathrm{~g}$, and $1 \mathrm{~g}$, in increasing order of the PGA and the second part evaluated the performance of hillside slope (slope angles $60^{\circ}, 45^{\circ}$, and $25^{\circ}$ ) 
TABLE 1: Description of used symbols in different curves.

\begin{tabular}{|c|c|}
\hline Symbols & Description \\
\hline I $60^{\circ}$ & $\begin{array}{l}\text { Building on } 60^{\circ} \text { slope angle founded on isolated } \\
\text { footing }\end{array}$ \\
\hline $\mathrm{R} 60^{\circ}$ & Building on $60^{\circ}$ slope angle founded on raft footing \\
\hline I $45^{\circ}$ & $\begin{array}{l}\text { Building on } 45^{\circ} \text { slope angle founded on isolated } \\
\text { footing }\end{array}$ \\
\hline $\mathrm{R} 45^{\circ}$ & Building on $45^{\circ}$ slope angle founded on raft footing \\
\hline I $25^{\circ}$ & $\begin{array}{l}\text { Building on a } 25^{\circ} \text { slope angle founded on isolated } \\
\text { footing }\end{array}$ \\
\hline $\mathrm{R} 25^{\circ}$ & $\begin{array}{l}\text { Building on a } 25^{\circ} \text { slope angle founded on isolated } \\
\text { footing }\end{array}$ \\
\hline Fixed ISO & Building with fixed, stepped isolated footing \\
\hline Fixed raft & Building with fixed raft footing \\
\hline
\end{tabular}

under static and seismic loads with and without constructed building to evaluate the static and dynamic stability of the hillside slope.

Figure 4 represents the straining actions of the analyzed model, using El Centro earthquake time history, taking into consideration the various types of slope angles, ground accelerations, and foundation systems (isolated or raft foundation system). Figure 4(a) shows variations of normal force in base columns, for a building founded at a $60^{\circ}$ slope with raft foundation and the normal force recorded the highest value with respect to the other cases. The greater the slope angle the greater the normal forces.

Figure 4(c) shows bending moment for base column. A maximum bending moment occurs in raft foundation on slope angle $60^{\circ}$ in $1 \mathrm{~g}$ acceleration, but in $0.50 \mathrm{~g}$ acceleration the maximum value was found in raft foundation with $45^{\circ}$ slope angle. Figure 4(d) represents the top floor displacement and the maximum value of displacement for the tested model was founded in raft foundation on slope angle $60^{\circ}$; this behavior was repeated in all used accelerations.

Table 1 describes the used symbols in different curves.

Figure 4(e) shows the values of top floor acceleration of the building model the maximum top floor acceleration was registered in the case of raft foundation on a $25^{\circ}$ slope angle, nearly 2.4 times the applied acceleration on the model for $1 \mathrm{~g}$ acceleration, 2.7 times the applied acceleration $(0.50 \mathrm{~g})$, and equals to 2 times the applied acceleration $(0.25 \mathrm{~g})$, from figure its can improved that the slope has not effect on the values of bending moment of base column except for R 25 (raft foundation on hillside slope $25^{\circ}$ ) nearly increased by 1.75 times than all cases, the bending moments in fixed base cases registered a lower value with respect to the rest cases.

Figure 5 shows the straining actions of the analyzed models, using Northridge time history earthquake model, taking into consideration the various types of slope angles, ground accelerations, and foundation systems (stepped isolated or raft foundation system). Figure 5(a) shows the variation of normal force in base columns, and building founded on $60^{\circ}$ slope with raft foundation gives the highest value of the normal force with respect to the other cases (nearly more than the other cases by 2.5 times), the big slope effect on the oblique of the building so that the high value of normal force. Figure 5(b) illustrates that base shear force at the raft foundation system in $60^{\circ}$ slope angle gives the maximum value with respect to the other slopes and a foundation system; this phenomenon was repeated for the three selected ground accelerations.

Figure 5(c) shows that base bending moment for base column maximum bending moment occurs in raft foundation case on slope angle $60^{\circ}$ and raft on slope $25^{\circ}$ in $1 \mathrm{~g}$ acceleration, but in $0.50 \mathrm{~g}$ and $0.25 \mathrm{~g}$ acceleration the values were nearly constant. Figure 4(d) represents the top floor displacement and the maximum value of displacement of the tested models, displacement of model in $60^{\circ}$ slope was smaller than in $25^{\circ}$ by 1.15 times, and this behavior was repeated in all used accelerations.

Figure 5(e) shows the values of top floor acceleration of models, and the maximum top floor acceleration was registered in the case of raft foundation on a $25^{\circ}$ slope angle, nearly 1.6 times the applied acceleration on the model for $1 \mathrm{~g}$, $0.50 \mathrm{~g}$, and $0.25 \mathrm{~g}$ cases of the applied acceleration.

The results founded from El Centro earthquake excitation were in the same trend with Northridge earthquake exaltation.

Figure 6 displays the stress distribution in $x$ - and $z$ directions of $2 \mathrm{D}$ slopes (angles $60^{\circ}, 45^{\circ}$, and $25^{\circ}$ ) under static condition. Figure 6(c) shows the stress distribution in $x$ and $z$-directions, and all stresses are negative (compression stress) with the allowable stress for the rocky soil of the hillside, in Figure 6(b) stress in the hillside with slope $45^{\circ}$ with moderate compression stress, but in Figure 5(a) the stress also in compression but with low value that because of the higher value of slope angle $60^{\circ}$.

To evaluate the effect of different kind of foundation system on hillside slopes under El Centro earthquake with $0.25 \mathrm{~g}, 0.5 \mathrm{~g}$, and $1 \mathrm{~g}$ PGA (Pick Ground Acceleration) excitation, there are three actual slopes that were tested $\left(60^{\circ}\right.$, $45^{\circ}$, and $25^{\circ}$ ). Only hillside slopes under $1 \mathrm{~g}$ PGA are shown in Figure 7. A hillside slope $25^{\circ}$ subjected to El Centro earthquake with PGA $1 \mathrm{~g}$ with raft foundation, stress in $x$ direction no tension between foundation, and soil underneath the model and so in $z$-direction generally no tension stress come out in the whole of the slope. The surface of failure appears under raft foundation more straight, but for steeped foundation the surface looks like a quarter circle (critical circle of slip). Compression stress in hillside slope underneath steeped foundation is bigger than raft foundation.

For a hillside slope angle 45 the straining action on the slope is moderate without tension stress between raft foundation in $z$-direction and the hillside soil will, but there is a tension stress between the raft foundation building model and the hillside soil in $x$-direction, which means collapse of the building model, there is a tension stress in the hillside slope in a crest parts, and the steeped foundation shows a minimum effect on the slope. This appears as a small value of compression stress in both directions and no tension stress appears underneath the steeped foundation of the model.

For hillside slope angle $60^{\circ}$ deformation of hillside slope with raft foundation a small part of the hillside will take off, a tension stress appears underneath the foundation in both 


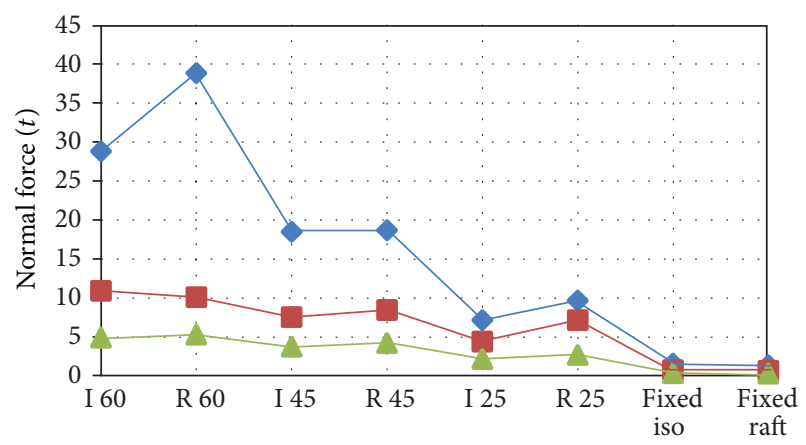

Foundation system with slope

$$
\begin{aligned}
& -\mathrm{N} 1 \mathrm{~g} \\
& -\mathrm{N} 0.5 \mathrm{~g} \\
& -\mathrm{N} 0.25 \mathrm{~g}
\end{aligned}
$$

(a) Base column normal force

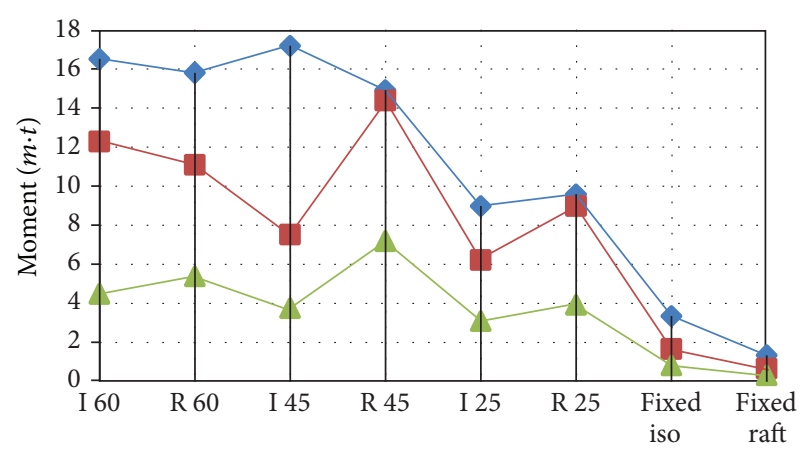

Foundation system with slope

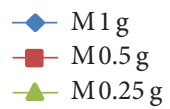

(c) Base column bending moment

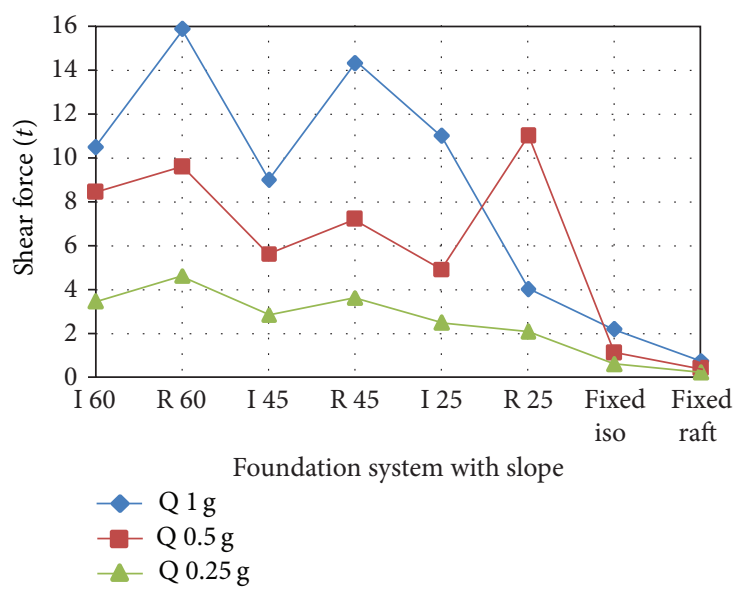

(b) Base column shear force

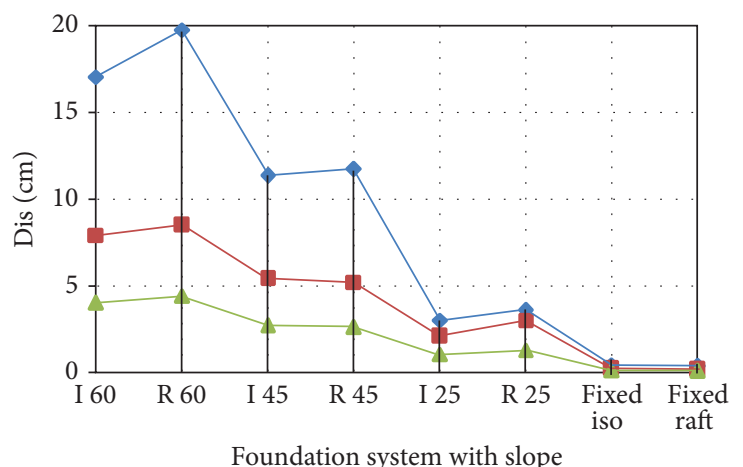

$$
\begin{aligned}
& - \text { Dis } 1 \mathrm{~g} \\
& - \text { Dis } 0.5 \mathrm{~g} \\
& - \text { Dis } 0.25 \mathrm{~g}
\end{aligned}
$$

(d) Displacement of top floor

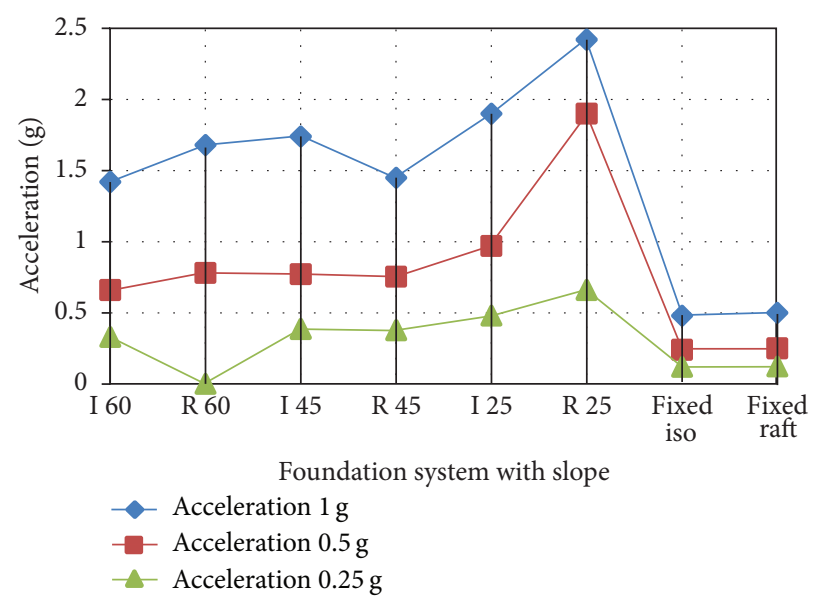

(e) Acceleration of top floor

FIGURE 4: Straining actions of 2D building with different types of foundation system and slope angle with El Centro earthquake excitation.

directions, and stepped foundation model appears to be more stable than raft foundation model because there is no tension between foundation and soil.

If the PGA equal to $0.5 \mathrm{~g}$ for the hillside slope $25^{\circ}$ no tension between both types of foundation and the soil underneath, both stress are compression in both directions, which have a large values. In hillside slope $45^{\circ}$ stress underneath a raft foundation model approximates to zero in both directions and this means the model is about rotation to be destroyed, but the steeped foundation was 


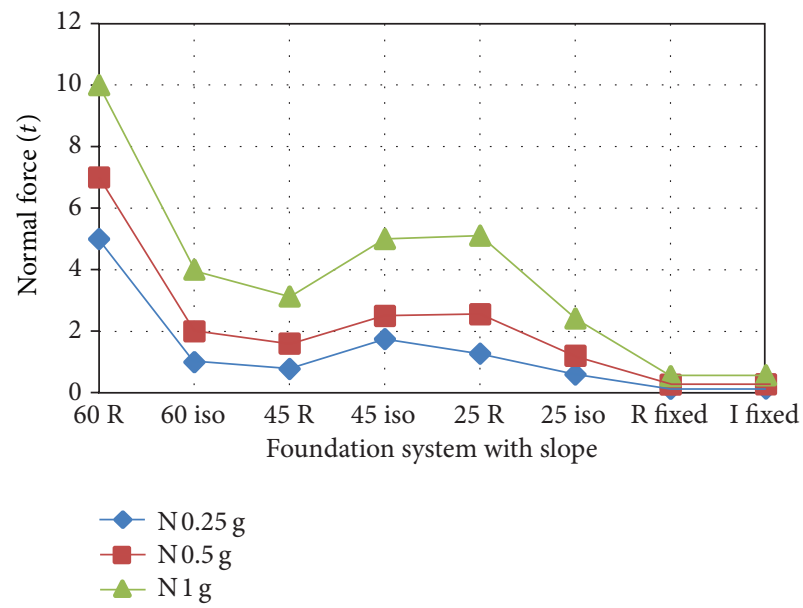

(a) Base column normal force

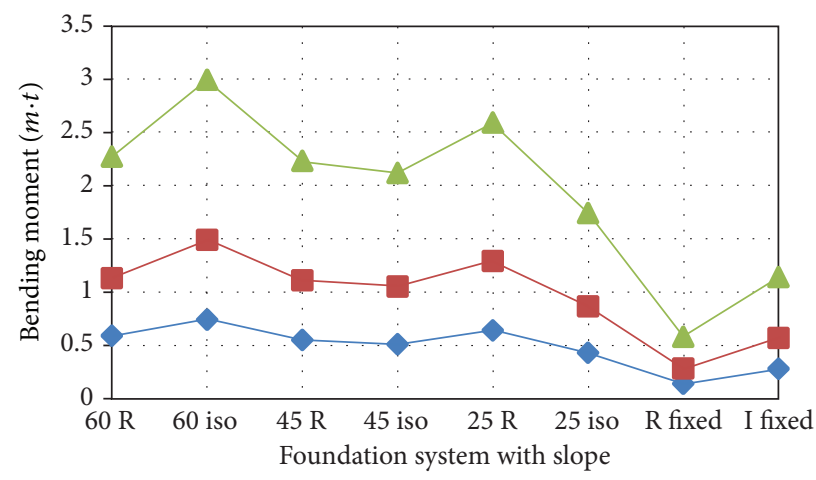

$-\mathrm{M} 0.25 \mathrm{~g}$
$-\mathrm{M} 0.5 \mathrm{~g}$
$-\mathrm{M} 1 \mathrm{~g}$

(c) Base column bending moment

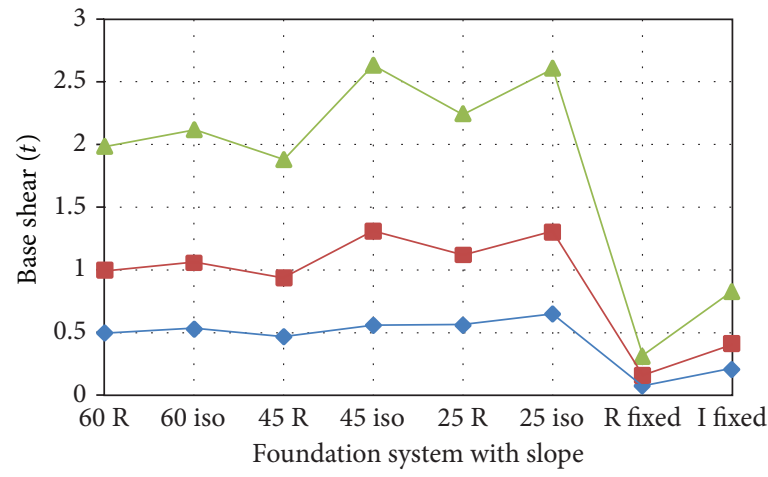

Q $0.25 \mathrm{~g}$

$\mathrm{Q} 0.5 \mathrm{~g}$

- Q 1g

(b) Base column shear force
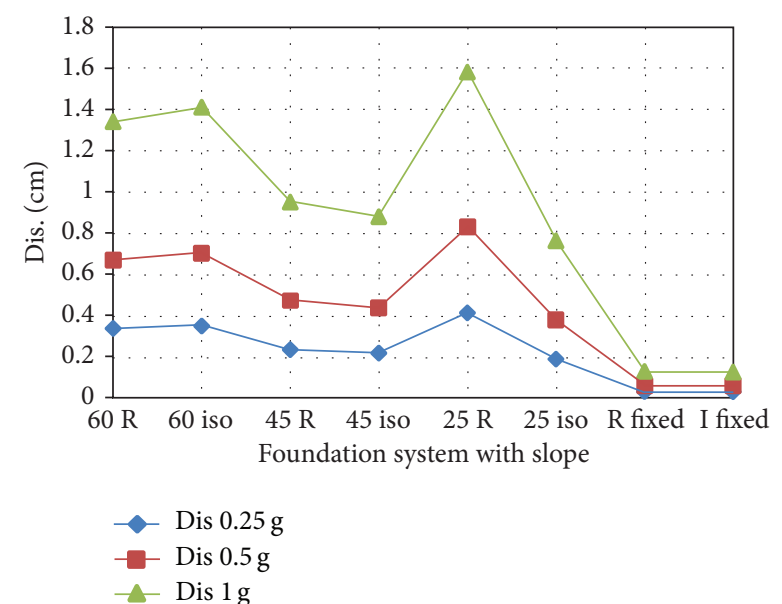

(d) Displacement of top floor

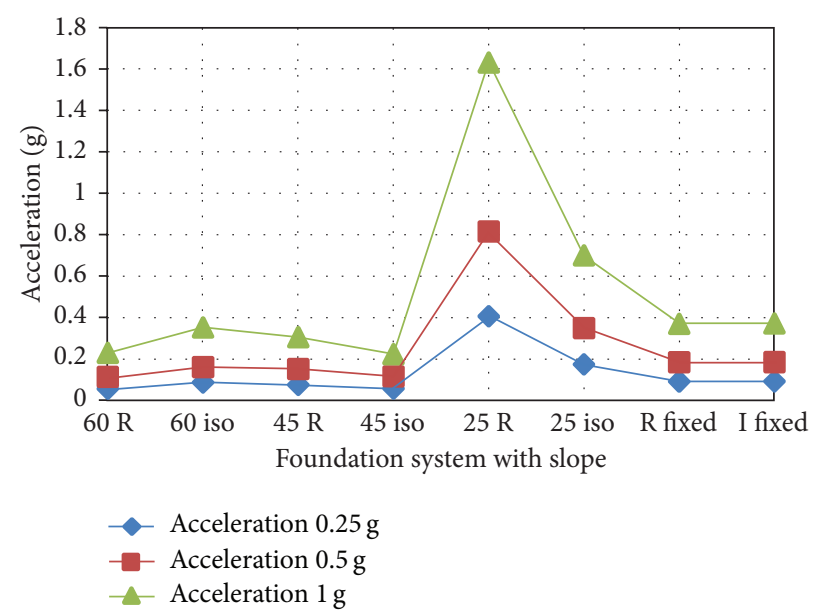

(e) Acceleration of top floor

FIGURE 5: Straining actions of 2D model with different types of foundation and slope angles with Northridge earthquake. 


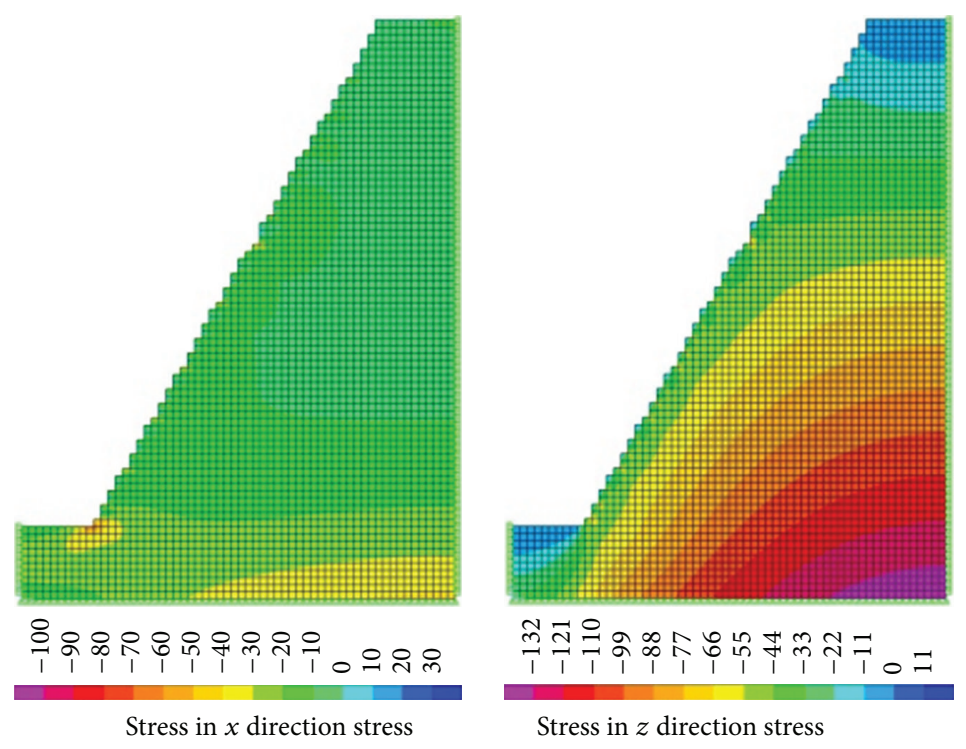

(a) Slope $60^{\circ}$

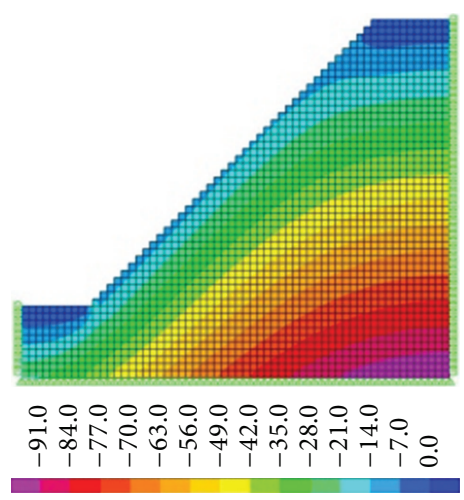

Stress in $z$ direction stress

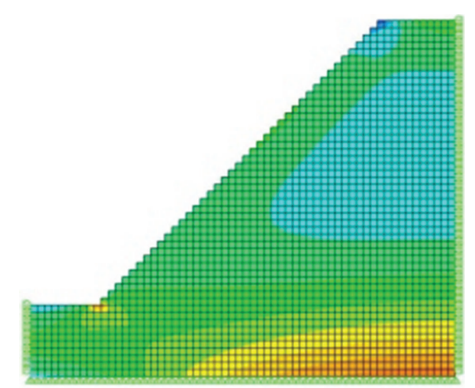

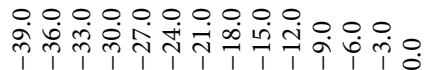

Stress in $x$ direction stress

(b) Slope $45^{\circ}$

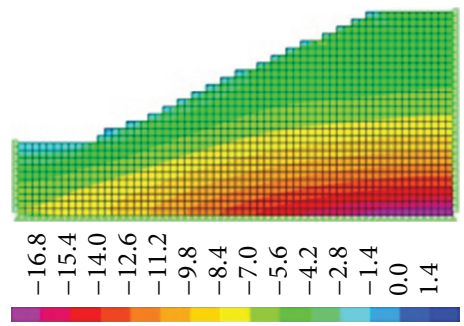

Stress in $x$ direction stress

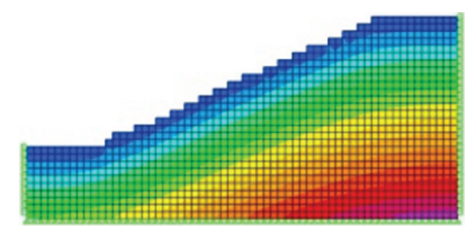

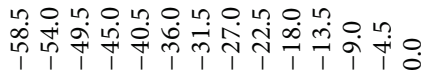

Stress in $z$ direction stress

(c) Slope $25^{\circ}$

FIgURE 6: Stress distribution on 2D slope with different slope angles under static load.

more stable, because there is a small value of compression stress underneath foundation. For a hillside slope angle 45 the straining action on the slope is moderate without tension stress between raft foundation in $z$-direction and the hillside soil will, but there is a tension stress between the raft foundation building model and the hillside soil in $x$-direction, which means collapse of the building model, and there is a tension stress in the hillside slope in a crest parts, and the steeped foundation shows a minimum effect on the slope. This appears as a small value of compression stress in both directions and no tension stress appears underneath the steeped foundation of the model.

Figure 8 illustrates the straining actions of the hillside slope under Northridge earthquake excitation with different kinds of foundation systems and slopes. For PGA 1g, slope $60^{\circ}$ there is a tension stress between foundation and soil on the slope; this indicated a failure of the model for both kinds of foundation (raft and stepped), deformation for stepped 


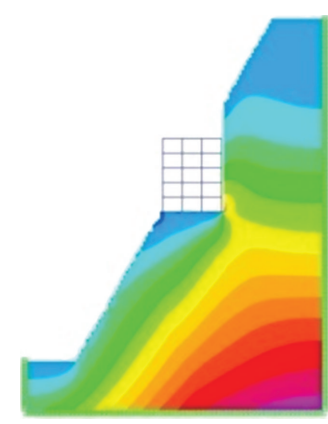

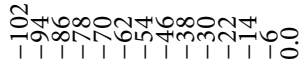

$z$ direction

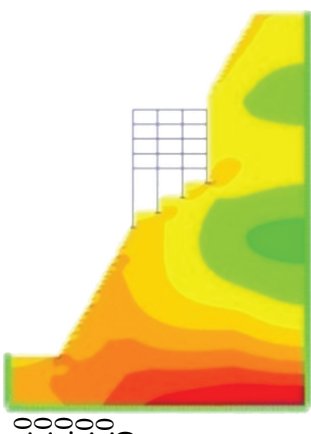

00000

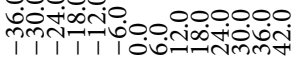

$x$ direction

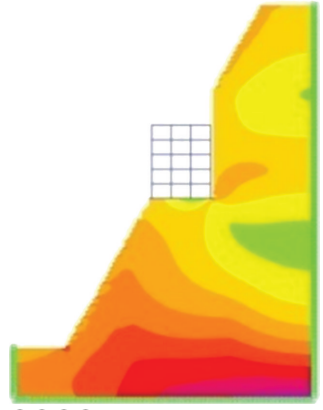

0000

mint

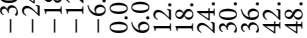

$x$ direction

(A) Raft foundation

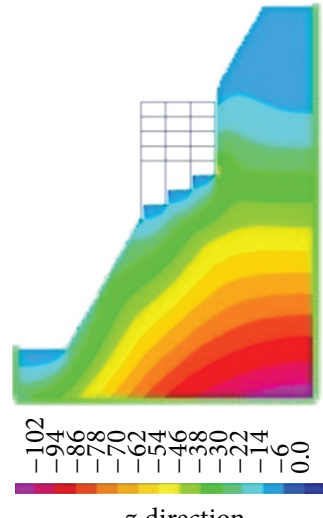

(B) Stepped foundation

(a) Straining action on slope $60^{\circ}$

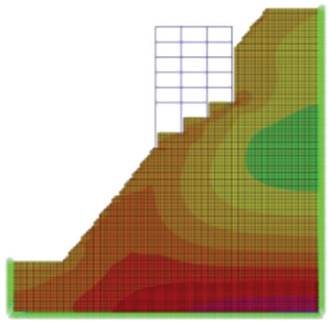

00000

4ก-

1. on

$z$ direction

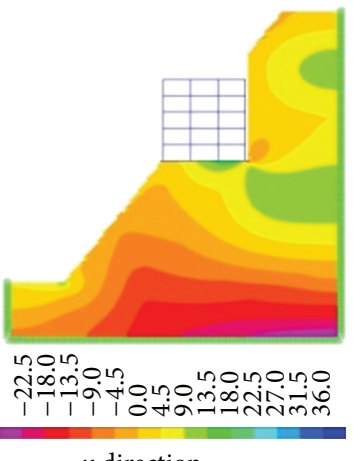

$x$ direction

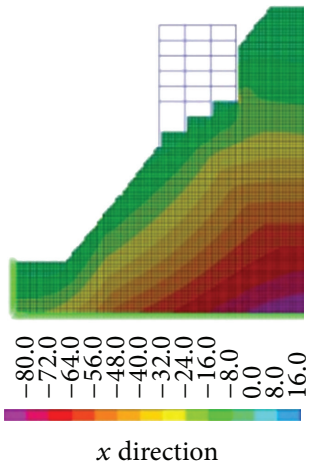

(A) Stepped foundation

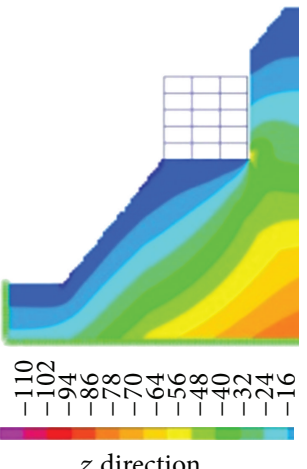

(B) Raft foundation

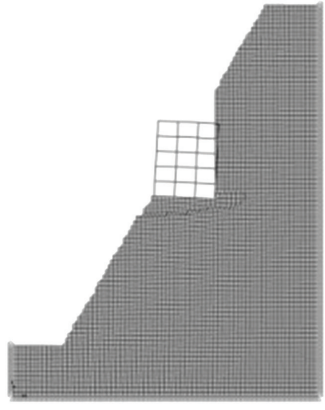

Deformation

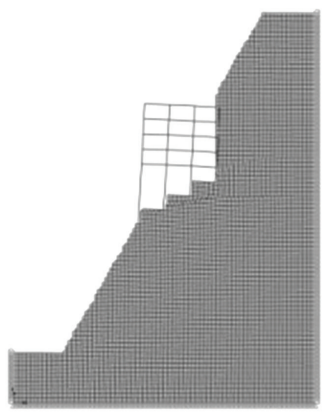

Deformation

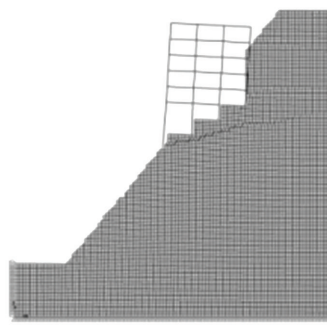

Deformation

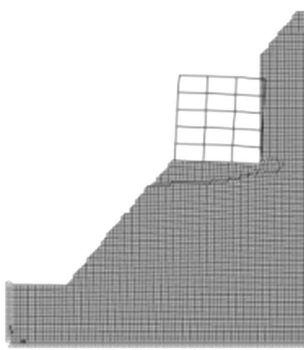

Deformation

(b) Straining action on slope $45^{\circ}$

FIgUre 7: Continued. 


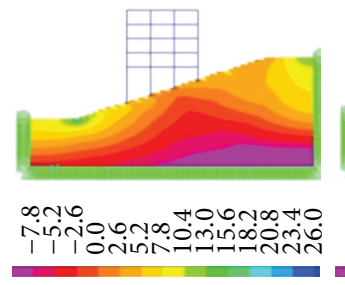

$z$ direction
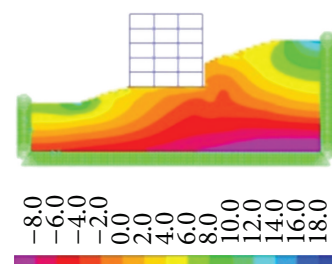

$x$ direction

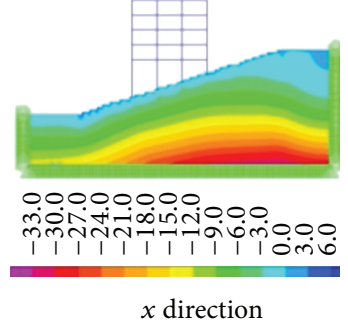

(A) Raft foundation

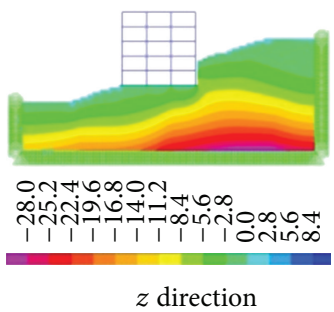

(B) Raft foundation

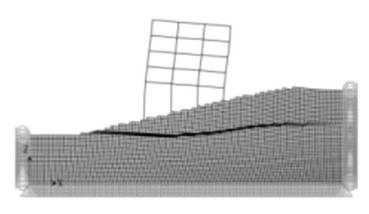

Deformation

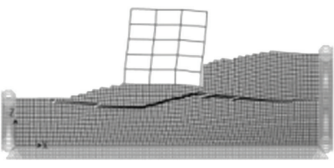

Deformation

(c) Straining action on slope $25^{\circ}$

FIGURE 7: Straining actions of 2D building with different types of foundation system and slope angle with El Centro earthquake excitation with PGA equal to $1 \mathrm{~g}$.

TABle 2: Conclusion of model stable with different earthquake PGA.

\begin{tabular}{|c|c|c|c|c|c|c|c|}
\hline \multirow{2}{*}{$\begin{array}{l}\text { Earthquake } \\
\text { acceleration }\end{array}$} & \multirow{2}{*}{$\begin{array}{l}\text { Hillside slope } \\
\text { angle }\end{array}$} & \multicolumn{2}{|c|}{ Static stability of slope only } & \multicolumn{2}{|c|}{$\begin{array}{l}\text { Dynamic stability with } \\
\text { constructed one building }\end{array}$} & \multicolumn{2}{|c|}{$\begin{array}{l}\text { Dynamic stability with } \\
\text { constructed series building }\end{array}$} \\
\hline & & Tension stress & $\begin{array}{l}\text { Compression } \\
\text { stress }\end{array}$ & $\begin{array}{l}\text { Tension stress } \\
\text { under building }\end{array}$ & $\begin{array}{l}\text { Compression } \\
\text { stress under } \\
\text { building }\end{array}$ & $\begin{array}{l}\text { Tension stress } \\
\text { under building }\end{array}$ & $\begin{array}{l}\text { Compression } \\
\text { stress under } \\
\text { building }\end{array}$ \\
\hline \multirow{3}{*}{$1 \mathrm{~g}$} & $60^{\circ}$ & No & Yes & Yes & - & Yes & - \\
\hline & $45^{\circ}$ & No & Yes & Yes & - & Yes & - \\
\hline & $25^{\circ}$ & No & Yes & No & Yes & Yes & - \\
\hline \multirow{3}{*}{$0.50 \mathrm{~g}$} & $60^{\circ}$ & No & Yes & Yes & - & Yes & - \\
\hline & $45^{\circ}$ & No & Yes & Yes & - & Yes & - \\
\hline & $25^{\circ}$ & No & Yes & No & Yes & - & Yes \\
\hline \multirow{3}{*}{$0.25 \mathrm{~g}$} & $60^{\circ}$ & No & Yes & Yes & - & Yes & - \\
\hline & $45^{\circ}$ & No & Yes & No & Yes & Yes & - \\
\hline & $25^{\circ}$ & No & Yes & No & Yes & - & Yes \\
\hline
\end{tabular}

foundation is bigger than a raft foundation model, and the straining action seems to be lower than the corresponding values of El Centro earthquake exaltation. For slope $45^{\circ}$ and $1 \mathrm{~g}$ PGA there is no tension stress between foundation and soil on the hillside slope, but the compression stress in the slope is small with respect to $60^{\circ}$ slope, and the corresponding values in $25^{\circ}$ slope are bigger than $45^{\circ}$ and no tension stress appears.

The results obtained from Northridge earthquake are similar in trend with these founded from El Centro earthquake excitation.

Table 2 concluded the results of model stress founded on the slopes with the view of stability or not under different earthquake excitation. The stability of a series of building construction on a slope under earthquake excitation was studied and also concluded in Table 2. It seem that series buildings can be more critical than one building and it is shown that the construction of series buildings on a slope from 60 to 45 angle can be destroyed under moderate earthquake, even so, the series buildings withstand the same earthquake magnitudes if it is founded on a flat land foundation.

\section{Conclusions}

A 2D building model founded on a hillside slope was evaluated to check the performance of buildings and slopes under various earthquake time history excitation and magnitude, studying a real case of study in a Doronka village in Upper Egypt. Two earthquake time histories were used El Centro and Northridge earthquake with $0.25 \mathrm{~g}, 0.5 \mathrm{~g}$, and $1 \mathrm{~g}$ PGA magnitude. The models used were prepared to agree with the 


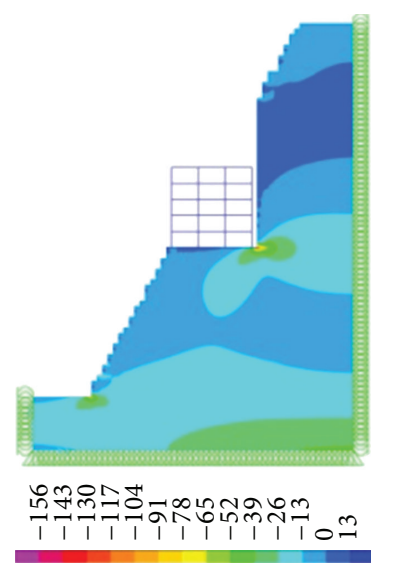

$Z$ direction

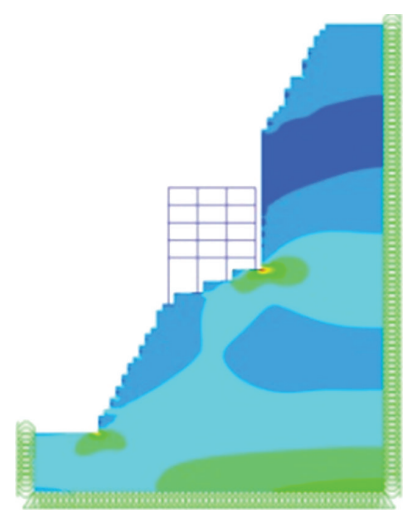

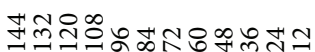

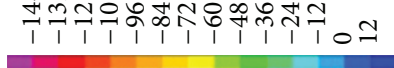

$x$ direction

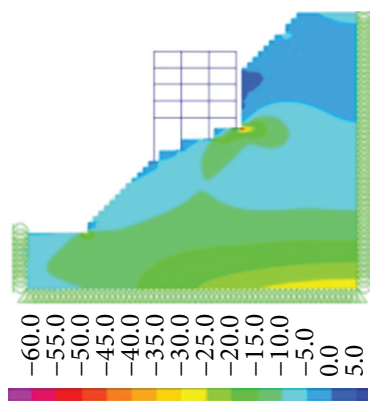

$z$ direction

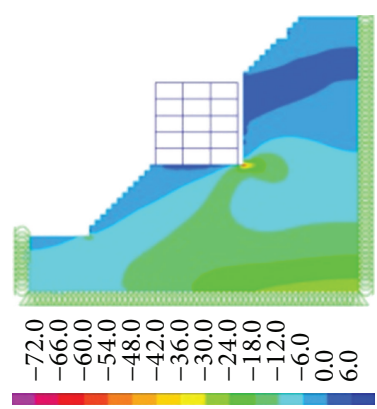

$x$ direction

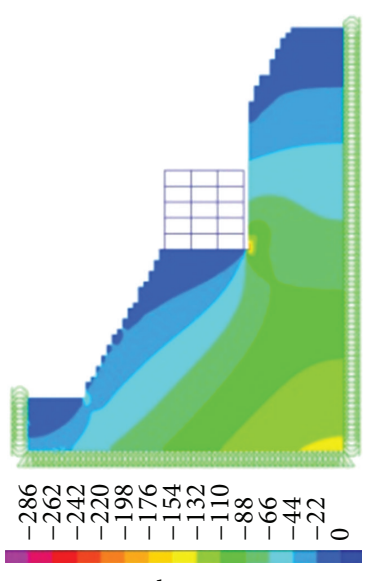

$X$ direction

(i) Raft foundation

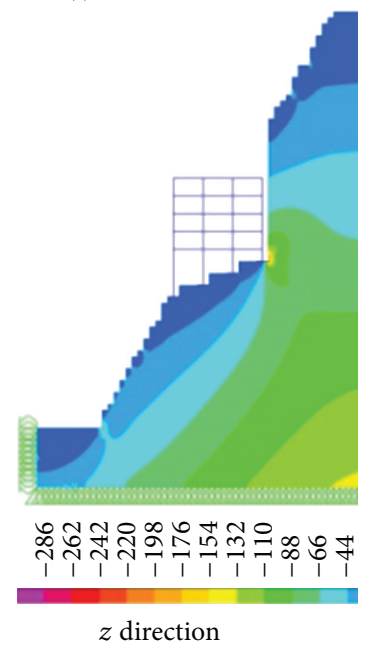

(ii) Stepped foundation

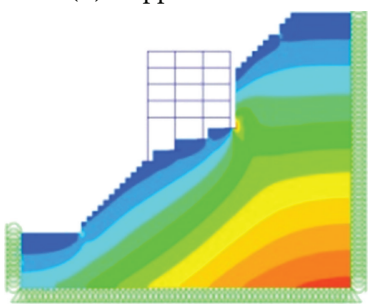

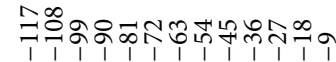

$x$ direction

(iii) Stepped foundation

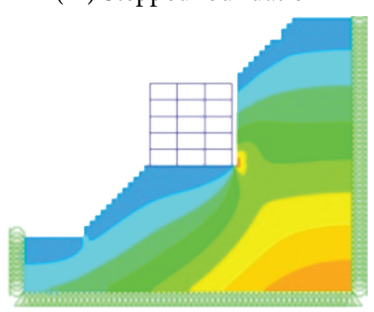

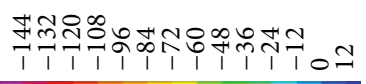

$z$ direction

(iv) Raft foundation

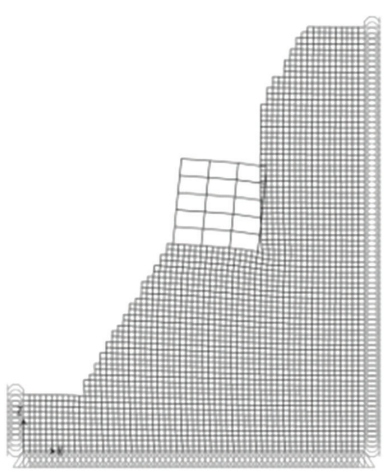

Deformation

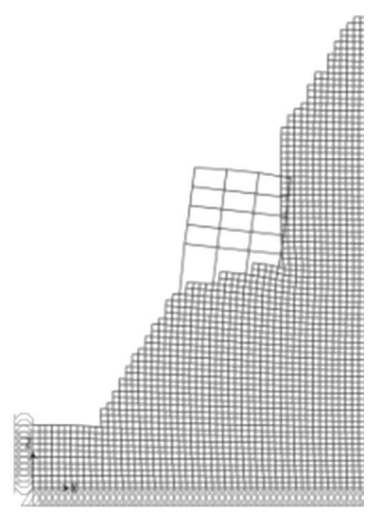

Deformation

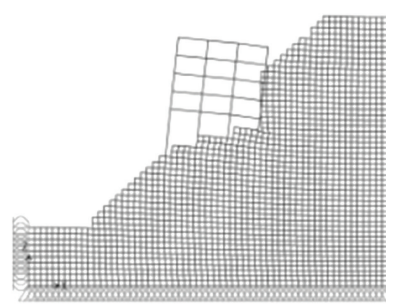

Deformation

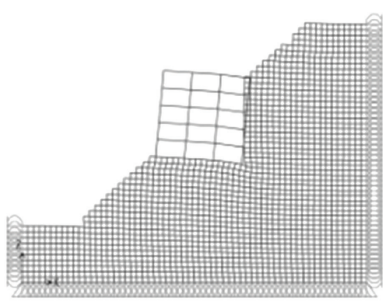

Deformation

(a) Straining action on slope $45^{\circ}$

Figure 8: Continued. 


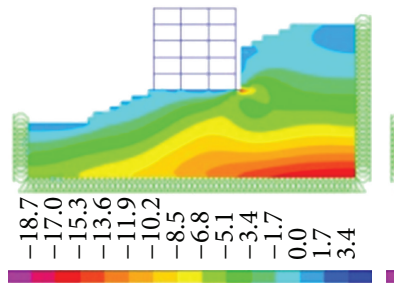

$z$ direction

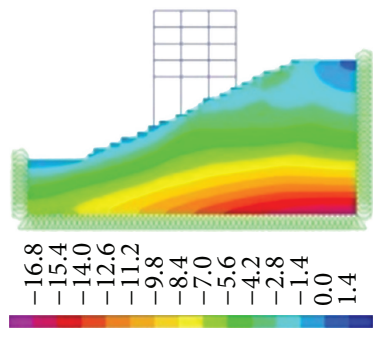

$x$ direction

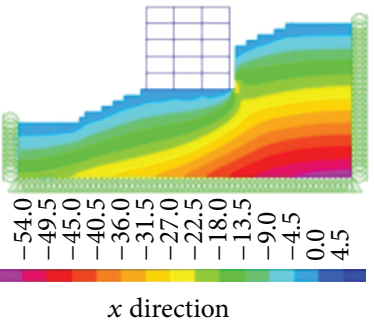

(v) Raft foundation

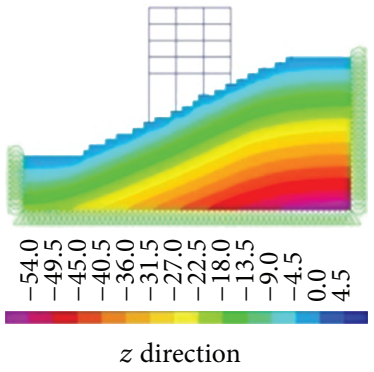

(vi) Stepped foundation
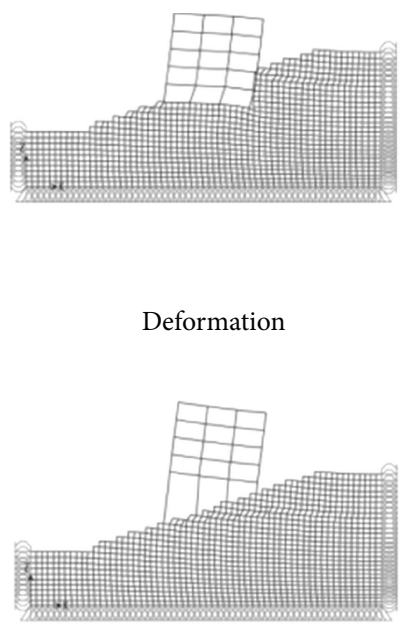

Deformation

(b) Straining action on slope $25^{\circ}$

FIGURE 8: Straining actions of 2D building with different types of foundation system and slope angle with Northridge earthquake excitation with PGA equals $1 \mathrm{~g}$.

reality of the nature of the case study, and the slopes were $60^{\circ}$, $45^{\circ}$, and $25^{\circ}$ and the foundation system to be stepped isolated or raft foundations. The nonlinear parameters of the rocky type soil were provided to SAP2000 program as a curve of soil under cyclic loading. Applying the two selected earthquake time histories with different PGA on a free hillside slope from building and with only one building and then with a series of buildings, the highlight points can be drawn as follows.

(i) Static analysis of hillside with different angles of slopes was found to be stable.

(ii) The study gives an overview of the stability of hillside slopes under earthquake excitations especially for construction requirements.

(iii) The stability of slopes (without constructing buildings) (with slope angles range from $60^{\circ}$ to $25^{\circ}$ ) is acceptable in the high PGA for the study of rocky soil; no tensile stress was found in the hillside slope.

(iv) Compression stress in a hillside slope angle $60^{\circ}$ decreased by 1.5 times than hillside slope angle $45^{\circ}$ and decreased by 1.4 times than hillside slope $25^{\circ}$ under seismic excitations.

(v) The interplay between dynamic "inertial" effects arising from the ground vibration and the quasistatic "kinematic" effects arising from the downward movement of a shallow sliding soil wedge are studied. It was thus determined that a rigid raft foundation, placed on a big angle slope which is in a precarious equilibrium and fails during very strong shaking, cannot protect the superstructure from both falling (being dragged) with the sliding soil mass and from suffering large damaging internal forces. (vi) This is in qualitative agreement with several case histories of structures that have survived the combined effects of strong seismic shaking and of soil downward sliding. The penalty to pay, however, is (a) appreciable rotation and lateral displacement of the whole system which may impair the serviceability of the structure and (b) generation of large bending moments and shear forces in the foundation slab by contrast, as in fact, most engineers would have intuitively predicted, placing a structure with isolated footings on a seismically unstable slope would be a prudent decision.

(vii) It is recommended to flatten the slope from $60^{\circ}$ to $45^{\circ}$ to avoid wedge failures at all isolated stepped foundation locations (normal force decreased by $50 \%$ for a slope angle $60^{\circ}$ than slope angle $45^{\circ}$ and base shear decreased by $40 \%$ in a slope angle $60^{\circ}$ than slope angle $45^{\circ}$ ).

(viii) The difference in straining action between steps and raft fixed base under dynamic loads is not significant (base shear in raft foundation increased by $2 \%$ than stepping isolated footing, $3 \%$ in bending moment, $5 \%$ in top displacement, and $7 \%$ in top floor acceleration).

(ix) Stepped isolated foundation represents the best solution for both dynamic performance of superstructure constructed on hillside slope and the stability of the slope (columns normal force for isolated footing decreased by 1.33 times than raft foundation and decreased by 1.45 times in base shear); in $2 \mathrm{D}$, the effect of the tie beams to connect stepped footing has been ignored. 
(x) Series buildings constructed on a hillside slope, especially $60^{\circ}$ angle normal force, increased by nearly 1.5 times than the one building model, 1.75 times for shear force, 1.40 times in bending moment, and 1.25 times for displacement and decreased by 0.20 times for top floor acceleration.

This conclusion drawn from a 2D analysis remains valid for the 3D cases, since more attenuation would be observed if the radiation damping into the third dimension was taken into consideration. These very local conditions are not adequately captured by the analysis. However, verification is required to check the results in $2 \mathrm{D}$ and $3 \mathrm{D}$.

\section{Conflict of Interests}

The author declares that there is no conflict of interests regarding the publication of this paper.

\section{References}

[1] E. Spencer, "A method of analysis of the stability of embankments assuming parallel inter slice forces," Geo-Technique, vol. 17, no. 1, pp. 11-26, 1967.

[2] H. S. Yu, R. Salgado, S. W. Sloan, and J. M. Kim, "Limit analysis versus limit equilibrium for slope stability," Journal of Geotechnical Engineering (ASCE), vol. 124, no. 1, pp. 1-11, 1998.

[3] A. Troncone, "Numerical analysis of a landslide in soils with strain-softening behaviour," Geotechnique, vol. 55, no. 8, pp. 585-596, 2005.

[4] D. Pitilakis, "Topographic irregularities and soil-foundationstructure interaction," in Proceedings of the 3rd Japan-Greece Workshop on Seismic Design, Observation and Retrofit of Foundations, pp. 335-343, Santorini, Greece, 2009.

[5] I. Anastasopoulos, G. Gazetas, M. F. Bransby, M. C. R. Davies, and A. El Nahas, "Fault rupture propagation through sand: finite-element analysis and validation through centrifuge experiments," Journal of Geotechnical and Geoenvironmental Engineering, vol. 133, no. 8, pp. 943-958, 2007.

[6] G. M. Latha and A. Garaga, "Stability analysis of a rock slope in Himalayas," Geomechanics and Engineering, vol. 2, no. 2, pp. 125-140, 2010.

[7] A. D. Pandey, P. Kumar, and S. Sharma, "Seismic soil structure interaction of buildings on hill slopes," International Journal For Computational Civil and Structural Engineering, vol. 2, no. 2, pp. 544-555, 2011.

[8] R. Kourkoulis, I. Anastasopoulos, F. Gelagoti, and G. Gazetas, "Interaction of foundation-structure systems with seismically precarious slopes: numerical analysis with strain softening constitutive model," Soil Dynamics and Earthquake Engineering, vol. 30, no. 12, pp. 1430-1445, 2010.

[9] S. Rampello, L. Callisto, and P. Fargnoli, "Evaluation of seismic coefficients for slope stability analysis using a displacementbased approach," in Proceedings of the Seismic Engineering International Conference Commemorating the 1908 Messina and Reggio Calabria Earthquake (MERCEA '08), 2008.

[10] R. L. Michalowski and L. You, "Displacements of reinforced slopes subjected to seismic loads," Journal of Geotechnical and Geoenvironmental Engineering, vol. 126, no. 8, pp. 685-694, 2000.
[11] D. S. Chavan, G. Mondal, and A. Prashant, "Permanent displacement of nailed soil slopes subjected to earthquake loading," in Proceedings of the 15th World Conference on Earthquake Engineering (WCEE '12), Lisbon, Portugal, 2012.

[12] A. Krishnamoorthy, "Factor of safety of a slope subjected to seismic load," Electronic Journal of Geotechnical Engineering, vol. 12, 2007.

[13] O. Mavrouli, J. Corominas, and J. Wartman, "Methodology to evaluate rock slope stability under seismic conditions at Solá de Santa Coloma, Andorra," Natural Hazards and Earth System Science, vol. 9, no. 6, pp. 1763-1773, 2009.

[14] ECOL 201, The Egyptian Code For Calculation of Loads and Forces in Structural Building Work, Housing and Building Research Center, Cairo, Egypt, 2008.

[15] SAP200, Nonlinear Version 14, Static and Dynamic Finite Elements Analysis of Structure, Computers \& Structures, Berkeley, Calif, USA, 2010.

[16] K. D. Hjelmstad, Fundamentals of Structural Mechanics, Springer, New York, NY, USA, 2nd edition, 2005. 

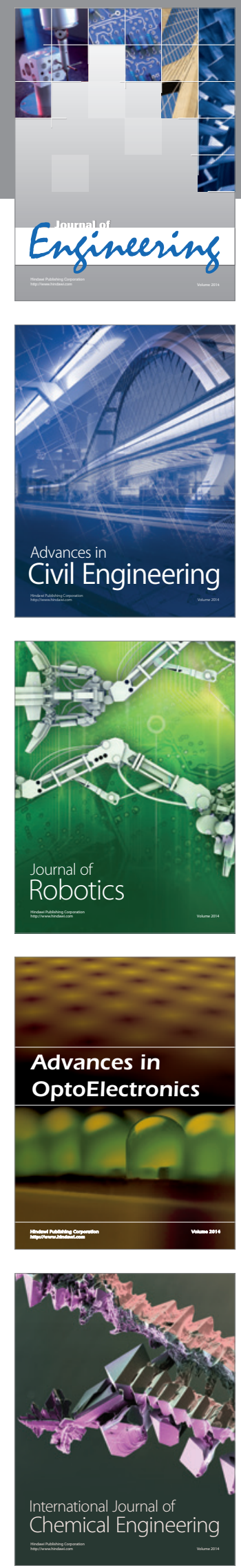

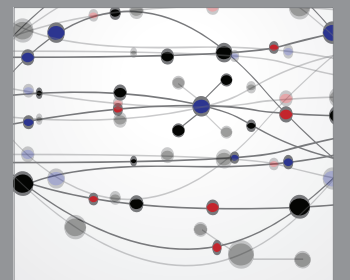

The Scientific World Journal
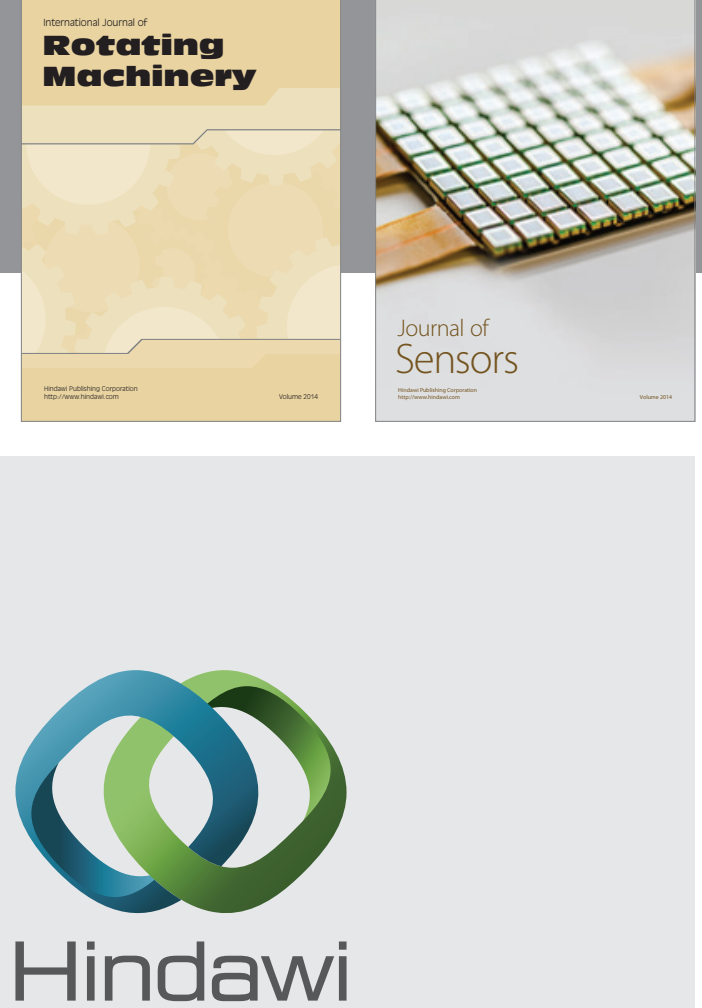

Submit your manuscripts at http://www.hindawi.com
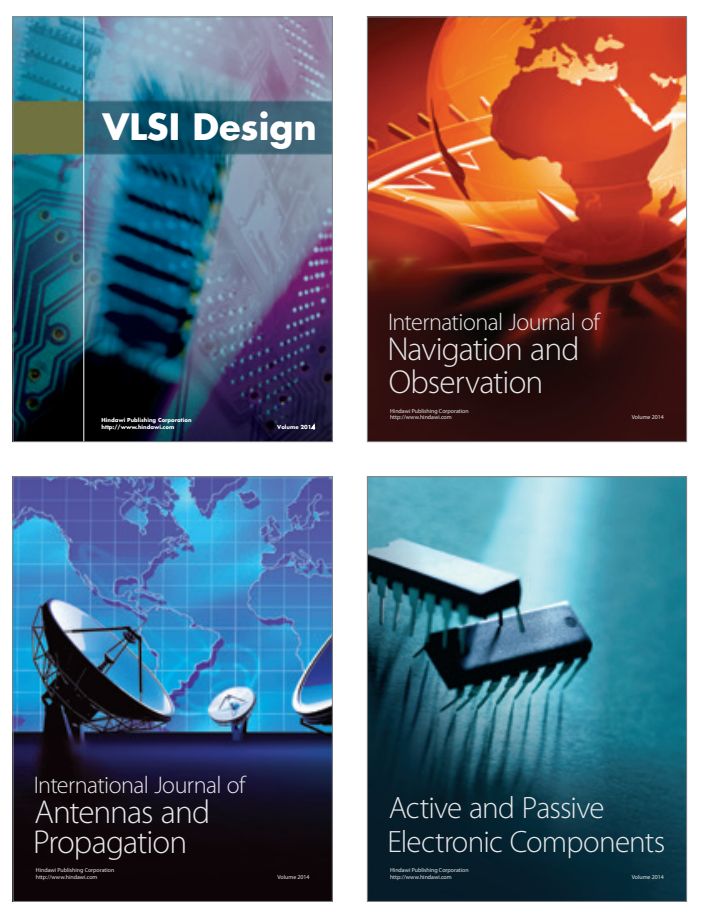
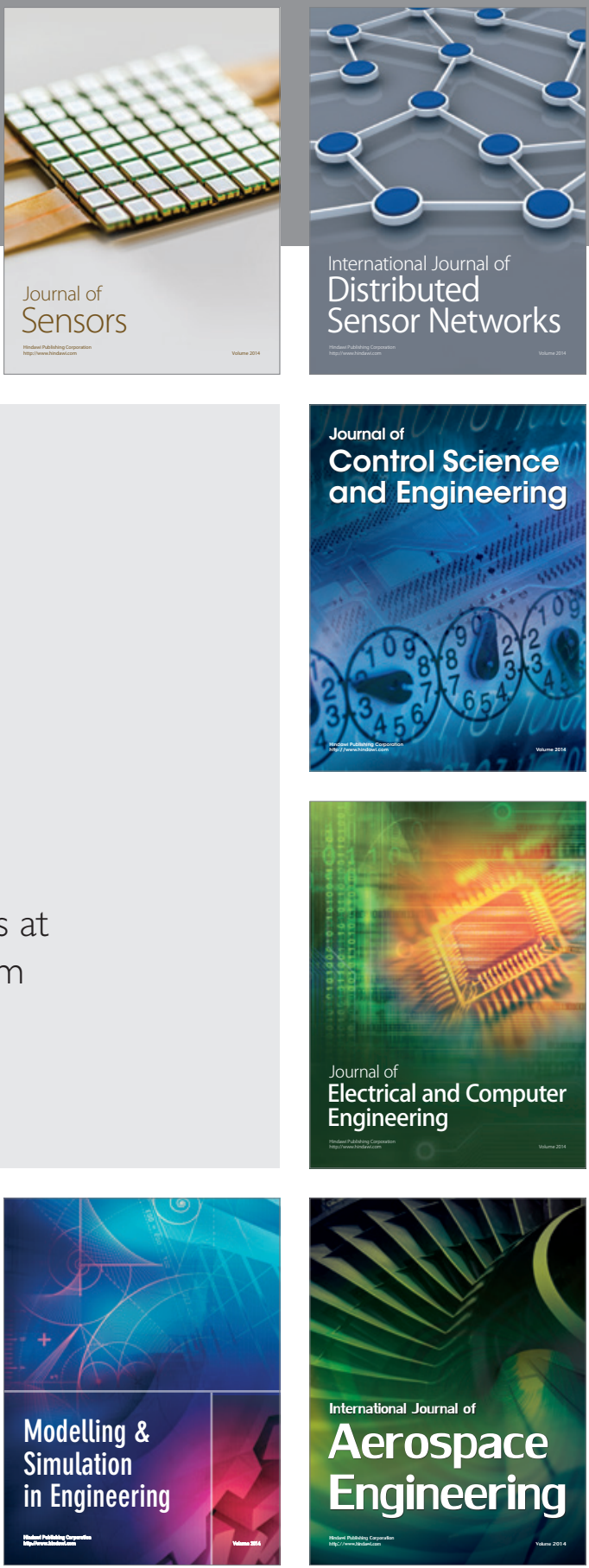

Journal of

Control Science

and Engineering
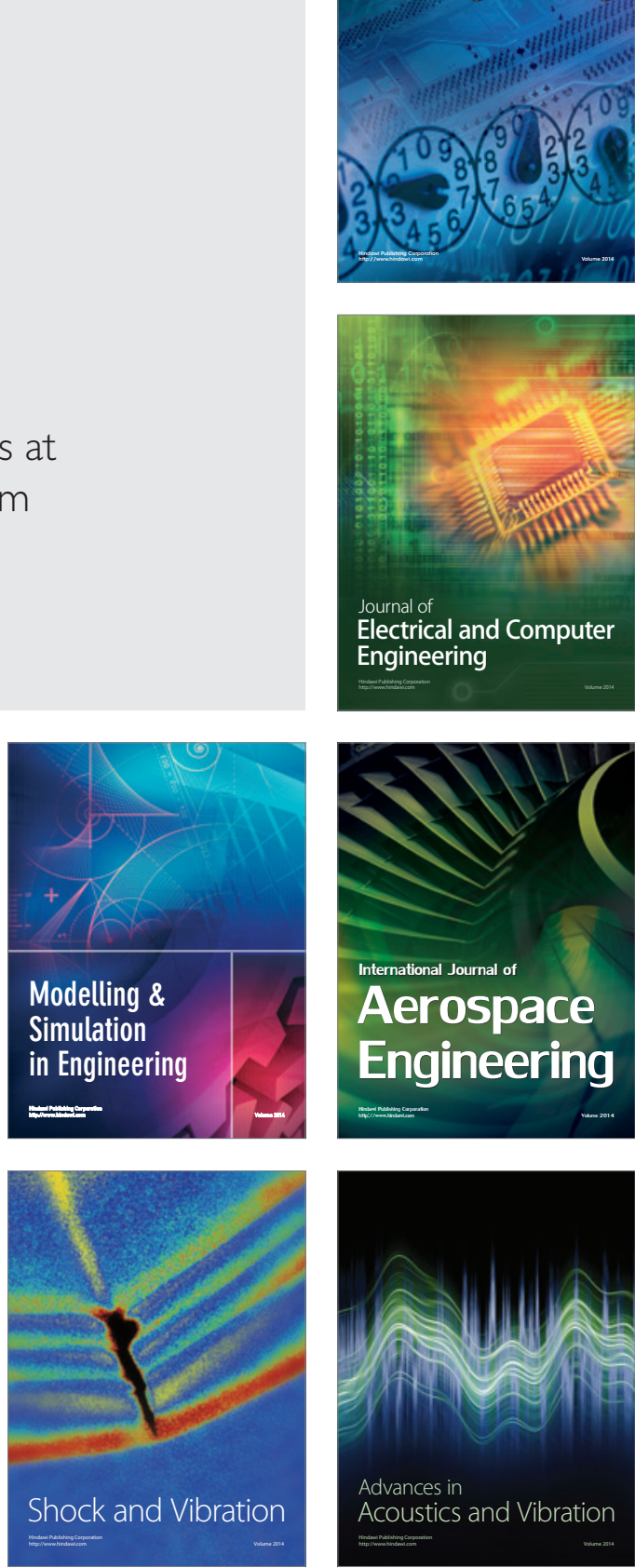